\title{
JOB CREATION AND JOB DESTRUCTION IN GREAT BRITAIN IN THE 1980s
}

\author{
DAVID G. BLANCHFLOWER and SIMON M. BURGESS*
}

\begin{abstract}
Using data from the Workplace Industrial Relations Surveys of 1980 , 1984 , and 1990, the authors investigate processes of job creation and job destruction in Britain. They find that rates of employment growth, job creation, and job destruction were higher at the end of the 1980 s than at the beginning. Both.job creation and job destruction were extremely concentrated: about $50 \%$ of each was accounted for by just $4 \%$ of continuing establishments. Employment growth was apparently more variable in manufacturing plants than in private service sector workplaces. Some variables negatively related to employment growth were unionization, establishment size, establishment age, and location in the private manufacturing sector (versus private service sector).
\end{abstract}

$\mathbf{E}$ conomists have long studied net changes in employment, but only lately have they turned their attention to gross flows. Typically, in this work they have set out to characterize the empirical properties of gross job flows. Perhaps the most striking finding from that literature is the great heterogeneity of employment growth experiences within very narrowly defined groups of firms or establishments. For example, even within 3- or 4-digit industries inside specific regions and age classes

\footnotetext{
*David Blanchflower is Professor of Economics at Dartmouth College and Research Associate at the National Bureau of Economic Research, and Simon Burgess is Reader at the University of Bristol. For helpful comments, the authors thank Patty Anderson, Andrew Chesher, Dan Hamermesh, Jonathan Leonard, Carol Propper, and seminar participants at the Labour Market Imperfections Group at Birkbeck College, London, and at the University of Bristol. Simon Burgess acknowledges funding through SPES grant no. CT91-0059 from the European Community.
}

of firms, there are simultaneous, and often substantial, job creation and job destruction. Researchers have also shown that job reallocation (the sum of job creation and destruction) is systematically related to age and size classes and to the state of the business cycle. Much of this work relates to manufacturing only, and most of it is limited to the private sector.

In this paper we examine job creation and destruction in Great Britain across all industries, in both the public and private sectors, using data from the Workplace Industrial Relations Surveys (WIRS) of 1980,

The data used in this paper are from the 1980 , 1984, and 1990 British Workplace Industrial Relations Surveys. These data are publicly available. The data extraction and analysis were performed using SPSSX on an IBM mainframe. The SPSSX programs are available from David G. Blanchflower, Department of Economics, Dartmouth College, Hanover, NH 03755. 
1984, and 1990. Each of these surveys covers some 2,000 establishments that compose a representative cross-section of continuing British establishments. We also report separate results by the age of the establishment, as well as by union status. This is new evidence. In addition, we look at the establishment-level analog of job reallocation and provide multivariate evidence on the important covariates of job reallocation. Previously, statements such as "Job reallocation decreases with age" have been based on simple bivariate crosstabulations over groups of establishments. We investigate the relationship in a multivariate context based on the establishment unit.

The data available to us also allow us to attack another problem: the size of withinfirm reallocations. Our data relate to establishments, but we can distinguish singleestablishment enterprises from enterprises that are part of multi-establishment firms. We can therefore isolate the difference in the job reallocation rate between singleand multi-establishment organizations, with a variety of other factors held constant.

\section{A Brief Survey}

One of the earliest analytical contributions on job creation and destruction and employment growth has become known as Gibrat's Law (Gibrat 1931). Gibrat's Law allows the derivation of a typical log normal distribution for firm size based on assumptions about the dynamic adjustment of employment and the distribution of the shock. While the evidence suggests that the results of this derivation do not provide the best fit to the data (see Chesher 1979, for example), most researchers today continue to derive the equilibrium size distribution from micro adjustment behavior (for example, Caballero 1992). A clear understanding of employment change at the establishment level is therefore important.

There are two main approaches to consider. One, which might be termed the empirical Industrial Organization approach, focuses on entry and exit data on firms or plants and the progress of en- trants. Examples of this approach are Geroski (1991), providing an excellent summary of the U.K. and U.S. evidence; Baldwin and Gorecki (1990), using a very rich Canadian database; and Dunne, Roberts, and Samuelson (1989b) and Pakes and Ericson (1990), examining U.S. data.

A principal finding of this empirical Industrial Organization research is that a large proportion of entrants are at the bottom end of the size distribution, but many of these small establishments survive for only a short time. A simple characterization of the process would be "up or out": entrants either are successful and grow (after about ten years they operate on the same scale as incumbents) or die off fairly quickly. In the United Kingdom, $5 \%$ of entrants disappear after their first year, and $30 \%$ have left within five years; a similar picture is true for the United States (see Dunne, Roberts, and Samuelson 1989b). There is thus substantial turnover of firms, and therefore of jobs, in most industries at most times, particularly among small firms. The marketplace acts as a filter, sorting viable projects from non-viable ones.

The second main approach focuses more directly on labor market flows. Much of the recent revival of interest in gross employment flows is due to the work of Dunne, Roberts, and Samuelson (1989a) and, even more so, Davis and Haltiwanger (1990, 1992), who exploited a large dataset on U.S. manufacturing plants. Davis, Haltiwanger, and Schuh (1994) presented a comprehensive view of the results on U.S. data. Also notable are studies presenting results for Italy (Contini and Revelli 1993), Germany (Boeri and Cramer 1991), and Belgium (Leonard and van Audenrode 1993). OECD (1994) summarizes the international evidence.

The main results of this literature can be summarized as follows. First, the amount of job creation and destruction is very large: in the United States, annual rates of job creation and destruction (defined below) in manufacturing are each of the order of $10 \%$. Second, job creation and destruction are pervasive and occur simultaneously in even very narrowly defined industries. 
Third, there are a few empirical regularities (see Blanchflower 1994). One of the patterns found is a tendency for job reallocation rates (the sum of job creation and job destruction rates) to decline with the size and age of the firm.

A number of issues have been underplayed in this literature. First, the empirical results presented are typically bivariate correlations-between, for example, job reallocation and age of plant. Sometimes these results are disaggregated by industry or size, but there does not seem to be much true multivariate analysis of the determinants of job reallocation. A second question arises from the distinction between firms and establishments. Some surveys use data on firms (enterprises) and some use data on plants (establishments); neither of these types of survey can address the question of how much reallocation occurs between establishments within firms.

Finally, we turn to the papers that have looked at gross employment flows in the United Kingdom; these are usefully summarized in Baldwin and Corecki (1990). One series of studies looks at regional and local areas (for example, Storey 1985). Another series of papers, by Gallagher and co-authors (Gallagher and Stewart 1986; Gallagher, Daly, and Thomason 1990, 1991; and Daly, Campbell, Robson, and Gallagher 1991), uses the Dun and Bradstreet credit rating database on U.K. private sector firms. Gallagher and his colleagues have established a number of facts about job creation and destruction and their relation to firm size. The central finding is the overwhelming importance of small firms to net job generation. However, few if any of these studies on gross employment flows in the United Kingdom look at annual changes (they take longer periods of varying length) or consider in any detail the nature of job creation and job destruction. Finally, they are restricted to the private sector.

Konings (1992) replicated the Davis and Haltiwanger study for the United Kingdom on a database of quoted (and therefore larger than average) manufacturing companies. He found the same pattern of the importance of idiosyncratic shocks and asymmetry of the gross flows as was found by Davis and Haltiwanger for the United States.

\section{Data}

The data used in this paper are taken from the Workplace Industrial Relations Surveys conducted in Great Britain in 1980, 1984, and 1990, known as WIRS1, WIRS2 and WIRS3, respectively. The surveys were sponsored by the Department of Employment, the Policy Studies Institute, the Economic and Social Research Council, and the Arbitration, Conciliation, and Advisory Service (ACAS). The level of observation is the establishment, defined as "[a place] of employment at a single address or site." To be included in the survey, an establishment had to have at least 25 employees (full- or part-time) both at the time the sample was drawn and at the time of the interview. In each case, the most recently available Census of Employment was used as the sampling frame; the 1977,1981 , and 1987 Censuses were used for WIRS1, WIRS2, and WIRS3, respectively. ${ }^{2}$ Establishments that came into being or ceased to exist during the period in question, as well as establishments that failed to meet the 25employee threshold at two points in time, are necessarily excluded from our analysis. Our sample thus represents the population of surviving establishments with at least 25 employees at the beginning and end of the periods 1977-80 (WIRS1), 1981-83 (WIRS2), and 1987-90 (WIRS3).

Because most establishments are small but large establishments account for a disproportionately high percentage of total employment, we oversample large establishments (where size is measured by employment). To compensate for this in-

\footnotetext{
"We use the terms "establishment" and "workplace" synonymously. The term "plant" is only used for manufacturing establishments.

'Sample sizes (unweighted) were: in 1980, $\mathbf{n}=$ 2,040 ; in 1984, $n=2,019$; and in 1990, $n=2,061$. For convenience, the results have been weighted to a base of 2,000 in each year.
} 
equality of selection, we weight the data. The surveys included personal interviews with the senior manager (dealing with employee relations, industrial relations, or personnel matters), other managers, and worker representatives. This paper uses only data from the senior manager's interview and the Basic Workforce Data Sheet, a self-completion questionnaire sent to managers several days prior to the main management interview. The samples are not panels." To construct the gross flows at sector and aggregate levels, we use the net employment change at the establishment level. This measure considerably understates the amount of worker turnover, because a given net change at the establishment level can result from simultaneous hiring and separations. Lane et al. (1992) showed that simultaneous hiring and separations are a significant phenomenon in the United States.

The population of workers covered by the WIRS series fell from 16.3 million in 1980 to 14.9 million in 1984 and increased to 15.6 million by $1990 .{ }^{4}$ The fall between 1980 and 1984 was largely due to the decline in the proportion of employees working in larger establishments, but was also due to a move toward smaller workplaces within the WIRS population. The mean size of workplaces in our data file was 118 employees in 1980, 109 in 1984, and 102 in 1990. In each of the three surveys, employ-

\footnotetext{
${ }^{3} \mathrm{~A}$ small panel of some 210 establishments (public and private sector) is also available for the years 1980-84. This panel proved too small for meaningful analysis. A larger trading sector panel is also available, with 537 cases for the years 1984-90. Our analysis of this panel proved to be unfruitful primarily because of discrepancies between data from the different surveys. In some cases it was apparent that the establishment had been defined somewhat differently over time, perhaps because of the long time that elapsed between the two interview dates, perhaps because of different respondents.

'There were 22,458,000 employees in June 1980, $20,741,000$ in June 1984 , and $22,325,000$ in June 1994. Consequently, WIRSI was representative of $72.6 \%$ of employees, compared with $71.8 \%$ for WIRS2 in 1984 and $69.9 \%$ for WIRS3 in 1990 . Source: Employment Gazette, January 1992.
}

ment growth is well below the national level, with the difference especially pronounced in $1983 / 84$, when the economy was just emerging from a deep recession. For the period $1979 / 80$, the number of employees in Great Britain fell by $0.8 \%$, compared with a fall of $1.6 \%$ for WIRS1. For the years $1983 / 84$ the figure was $+0.9 \%$ overall, compared with $-1.5 \%$ in WIRS2, and for $1989 / 90$ it was $+1.0 \%$, compared with $+0.1 \%$ in WIRS3. ${ }^{5}$

At this point it is appropriate to consider briefly the macroeconomic circumstances behind the changes in employment we observe in our samples of workplaces. Unemployment was around $5 \%$ in both 1980 and 1990 , with roughly the same number of employees (22 million), but in 1980 unemployment was at the start of a steep rise, whereas it was still falling in 1990. 1984 was at a trough of the cycle, with high unemployment $(10.7 \%)$ and low employment (20.7 million). Throughout the 1980 s there was a rapid decline in employment in manufacturing, from 6.8 million in 1980 to 5 million in 1990. (The decline continues; at the time of this writing, the figure is just over 4 million.) Manufacturing's share of employment fell from $31 \%$ in 1980 to $26 \%$ in 1984 and $23 \%$ in 1990 . The WIRS sample figures were $40 \%, 29 \%$, and $23 \%$, respectively. The mean size of manufacturing establishments in the WIRS was 185 in 1980 , 147 in 1984, and 128 in 1990. Private nonmanufacturing employment grew by $12 \%$ between 1984 and 1990 after a small contraction between 1980 and 1984. Largely through privatization, and more recently by the contracting out of services by public sector bodies, employment in the parts of the public sector covered by the WIRS sample fell from 1.3 million in 1980 to 0.8

'The interested reader can obtain further details on these surveys from the various source books: Daniel and Millward (1984) on WIRS 1; Millward and Stevens (1986) on WIRS2; and Millward, Stevens, Smart, and Hawes (1992) on WIRS3.

The figures on employees in Great Britain were obtained from Employment Gazette, May 1992, Table 1.2 . 
million in 1990 , with most of the change occurring after 1984.

\section{Results}

The rates of job creation and destruction (JC\&D) we refer to here are weighted summary statistics of the distribution of employment growth rates over firms or establishments. The employment growth rate for each workplace is simply the number of employees in period $t$, whether full-or parttime, minus employment in period $t-1$ as a proportion of employment in $t-1$. The job creation rate (JC) is the average employment growth rate among establishments that are growing, and the job destruction rate $(\mathrm{JD})$ is the absolute average employment growth rate among establishments where employment is falling; usually in the literature these figures are weighted by employment size (Davis and Haltiwanger 1990). Thus an understanding of JC\&D requires an understanding of this distribution. In this section we therefore look at features of this distribution before moving on to consider the job creation and destruction rates.

\section{Employment Growth}

Let the growth rate of employment in establishment $i$ at a particular date be $g_{i}$, with density function $f($.$) . Much attention$ has been given to the mean of the distribution, that is, if $f($.$) is written as g_{i} \sim(X \beta, \sigma)$, the focus is on $X_{i} \beta$. This follows naturally from studies of aggregate employment, where the prime concern is to model the evolution of the stock of employment. A number of authors have estimated models of employment growth for individual establishments (Blanchflower and Millward [1988] and Blanchflower, Millward, and Oswald [1991] for Great Britain; Long [1993] for Canada; Wagner [1992] for Germany; and Leonard [1992] for the United States) and a few for firms (Nickell and Wadhwani 1991; Bronars and Deere 1993; Freeman and Kleiner 1990). Many of these studies are based on the same labor de- mand approach used in the macroeconomics literature ${ }^{6}{ }^{\text {with the addition of the }}$ variety of controls available in a cross-section study. In this paper, we focus more on other aspects of the distribution that we believe to be important in understanding JC\&D.

Since the job creation and job destruction rates are simply the weighted means of different truncations of the distribution $f($.), clearly the variance and degree of skewness are likely to be important. In fact, a simple simulation suggests that they may be more important than the mean. If we initially start with a mean growth rate of $2 \%$ and an SD of 25, which, as we will show below, is approximately what we observe empirically, and increase the mean growth rate to $4 \%$, the $\mathrm{JC}$ rate remains roughly constant at $22.4 \%$ and the JD rate declines slightly from $19 \%$ to $17.5 \%$. In contrast, if we take the same starting values as before but simply increase the standard deviation from 25 to 35 , the JC rate jumps to 27.3 and the JD rate to 26.4. This relative dependence is clearly sensitive to the type of distribution chosen, but it is clear that the higher moments of the employment growth distribution such as the standard deviation are important to understanding the evolution of employment flows. ${ }^{7}$ Put another way, we are (1) investigating the diversity of experience in employment growth across establishments and (2) considering evidence on the factors that are associated with high variance among a particular subpopulation.

Table 1 shows the basic features of the data for the three cross-sections by sector,

\footnotetext{
${ }^{6}$ Typically, employment is related to the real wage, the capital stock, and demand shock variables.

${ }^{7} \mathrm{An}$ interest in the variance of employment growth rates in a cross-section is not new. Lilien (1982) examined the correlation of this variable with the aggregate unemployment rate. Davis and Haltiwanger (1990) considered explanations of the temporal pattern of job creation and destruction in terms of what they called "reallocation intensity." Reallocation intensity is clearly related to the variance of employment growth shocks across firms, though Davis and Haltiwanger did not express it in those terms.
} 
Table 1. Mean Employment Growth Rates by Sector (\%).

\begin{tabular}{|c|c|c|c|c|c|c|c|}
\hline \multirow[b]{2}{*}{ Sector } & \multicolumn{2}{|c|}{1980} & \multicolumn{2}{|c|}{1984} & \multicolumn{3}{|c|}{1990} \\
\hline & 1-Year & 5-Year & 1-Year & 4-Year & 1-Yẹar & 3-Year & 6-Year \\
\hline All Establishments & 1.6 & 14.0 & 2.3 & 4.7 & 3.8 & 14.1 & 36.4 \\
\hline Private Sector & 1.4 & 18.1 & 3.5 & 6.9 & 3.9 & 15.5 & 47.6 \\
\hline Public Sector & 2.1 & 5.7 & 0.1 & 0.7 & 3.6 & 10.5 & 8.1 \\
\hline Private Manufacturing & -1.9 & 14.7 & 1.4 & 7.2 & 1.9 & 13.6 & 53.8 \\
\hline Private Non-Manufacturing & 3.4 & 20.3 & 4.5 & 6.7 & 4.8 & 16.4 & 44.2 \\
\hline Union & 1.1 & 5.9 & 1.1 & -2.4 & 3.7 & 13.6 & 35.4 \\
\hline Nonunion & 2.5 & 29.1 & 4.6 & 18.1 & 4.8 & 17.2 & 42.8 \\
\hline
\end{tabular}

Notes: employment growth calculated as follows: $\frac{N_{t}-N_{t-1}}{N_{t-1}} * 100$ with the weights applied. These are unweighted means of the weighted data.

Base: All establishments reporting employment at the time of the survey and one year earlier.

Source: Workplace Industrial Relations Surveys (1980, 1984, and 1990).

where all data are weighted. ${ }^{8}$ In all three years it is possible to calculate for each establishment a one-year change. In addition, a five-year change is available in WIRS1, along with a four-year change in WIRS2 and both a six-year and a three-year change in WIRS3. These are the only employment numbers available to us. The mean oneyear growth rate of employment in this sample of surviving establishments increased from $1.6 \%$ in $1979-80$ to $2.3 \%$ in $1983 / 84$ and $3.8 \%$ in $1989 / 90$. Growth rates in the private sector tended to be higher than in the public sector. Nonunion workplaces grew considerably faster than union workplaces. One-year growth rates were much higher in private non-manufacturing than in private manufacturing, but the picture is reversed in the later two periods, where longer time changes are examined. At first glance, these are somewhat surprising results, but they presumably reflect the very low starting size in our surviving manufacturing establishments after the severe recession years of the early 1980s.
Table 2 reports not only mean employment growth rates by year but also indicators of the dispersion of employment growth between establishments. Once again, all data are weighted, although we report both the unweighted and weighted bases. Behind the summary statistic of mean growth lies considerable diversity. In particular, the 10-90 percentile range increased from 29.4 to 35.8 between 1980 and 1990 . The standard deviation also increased-from 18.9 to 29.2 -but the coefficient of variation actually fell (from 11.7 to 7.7 ) over the period because of the increase in the mean growth rate. Not only did the mean employment growth rate increase during the 1980 s, but so did the dispersion of these growth rates.

Table 3 provides a more detailed picture of the range and variability of the one-year employment growth rates for $1979 / 80$, $1983 / 84$, and $1989 / 90 .^{9}$ The main points that emerge are as follows.

(1) In each of the three parts of Table 3, just under half of all establishments were relatively stable (changed by between $+5 \%$ and $-5 \%$ ). Approximately one workplace in eight changed employment by at least

${ }^{9}$ Blanchflower and Millward (1988) and Blanchflower, Millward, and Oswald (1991) reported employment growth rates using the WIRS1 and WIRS2 data for five-year and four-year changes, respectively.

\footnotetext{
${ }^{8}$ In the sense described in the previous section; they are not further weighted by their size. This means that it is possible (as happens in 1980 and 1984) for the average growth rate to be positive, but total employment to fall.
} 
Table 2. Employment Growth Rates by Year (\%).

\begin{tabular}{|c|c|c|c|c|c|c|c|c|}
\hline \multirow[b]{2}{*}{ Year } & \multicolumn{6}{|c|}{ Weighted \% } & \multirow[b]{2}{*}{$\begin{array}{c}\text { Unweighted } \\
\text { Base }\end{array}$} & \multirow[b]{2}{*}{$\begin{array}{c}\text { Weighted } \\
\text { Base }\end{array}$} \\
\hline & Mean & Annualized & S.D. & Max. & Min. & $10-90$ & & \\
\hline \multicolumn{9}{|l|}{1980} \\
\hline 1-Year & 1.6 & - & 18.9 & 379.3 & -93.9 & 29.4 & 188 & 1,862 \\
\hline 5-Year & 14.0 & 2.7 & 68.6 & 3280.0 & -95.1 & 81.7 & 1,577 & 1,521 \\
\hline \multicolumn{9}{|l|}{1984} \\
\hline 1-Year & 2.3 & - & 21.4 & 314.3 & -94.3 & 27.9 & 1,813 & 1,862 \\
\hline 4-Year & 4.7 & 1.2 & 77.6 & 3450.0 & -96.1 & 68.4 & 1,624 & 1,620 \\
\hline \multicolumn{9}{|l|}{1990} \\
\hline 1-Year & 3.8 & - & 29.2 & 1003.2 & -97.1 & 35.8 & 1,705 & 1,766 \\
\hline 3-Year & 14.1 & 4.5 & 58.9 & 1241.2 & -97.2 & 65.5 & 1,441 & 1,507 \\
\hline 6-Year & 36.4 & 5.3 & 131.8 & 3928.8 & -97.0 & 114.6 & 1,191 & 1,237 \\
\hline
\end{tabular}

Notes and Source: See notes to Table 1.

$20 \%$ in a one-year period. The proportion of establishments that changed employment by at least $20 \%$ was greater in 1990 (16.6\%) than $1980(13.3 \%)$.

(2) Manufacturing shows the least stability of any sector: approximately $40 \%$ of establishments grew by less than $5 \%$ in absolute value, while around $17 \%$ experienced employment change in excess of $20 \%$. Over a longer horizon, this pattern is accentuated further. It is striking that even though the period 1980-84 is generally acknowledged to have been an extremely difficult one for manufacturing in Great Britain (particularly as measured by employment), $25 \%$ of manufacturing plants grew by $20 \%$ or more over that period, which is more than in private service establishments.

(3) Establishments in the union sector were less likely to grow greatly $(>20 \%)$ than were those in the nonunion sector. There is less evidence at the other end of the distribution that union workplaces were more likely to shrink substantially (that is, decline by more than $20 \%$ ). In all cases the variability of employment growth is greater in the nonunion sector than in the union sector. As might be expected, employment varies most in private sector nonunion establishments.

The relationship between the employment growth rate and the initial level of employment is important for the equilib- rium size distribution of establishments. Traditionally of interest is the relationship between the mean growth rate and size. Also relevant here is a comparison of the variability of employment growth across different size bands. The evidence is presented in Table 4.

First, the mean growth rate, which is reported in column 6 , is clearly declining in size. Small establishments tend to grow and large establishments tend to decline; this is necessary for a stable size distribution. In each of our three years, establishments with employment of 25-49 employees grew the fastest over the one-year period $(4.40 \%$ in $1980,4.31 \%$ in 1984 , and $6.95 \%$ in 1990). The largest workplaces (those with at least 1,000 employees), on average, shrank by around $4 \%(3.88 \%$ in $1980,3.97 \%$ in 1984 , and $3.40 \%$ in 1990 ). Hence the difference in growth rates between the smallest and largest establishments widened over the period $(8.3 \%$ in 1980 , compared with $10.3 \%$ in 1990). Otherwise, the differences in the distribution are not very marked. There is certainly little difference in the proportion of establishmen ts experiencing significant change: for example, in 1984, all size bands except the largest showed around $50 \%$ of establishments in the $-5 \%$ to $+5 \%$ range. Thus the relationship between size and the range of growth/decline rates is not as strong as might have been expected. 
Table 3. Employment Growth (\%) 1-Year Change.

\begin{tabular}{|c|c|c|c|c|c|c|}
\hline \multirow[b]{2}{*}{ Sector } & \multicolumn{5}{|c|}{ Proportion of Establishments with Employment Growth Rate (\%): } & \multirow[b]{2}{*}{$N$} \\
\hline & $\leq-20$ & $>-20 \mathcal{E}^{2} \leq-5$ & $>-5 \mathcal{E}^{2}<5$ & $\geq 5 \mathcal{E}^{\circ}<20$ & $\geq 20$ & \\
\hline \multicolumn{7}{|c|}{1980} \\
\hline All Establishments & 5.3 & 21.3 & 46.9 & 18.5 & 8.0 & 1,862 \\
\hline Private Sector & 6.5 & 20.7 & 44.5 & 19.4 & 8.9 & 1,270 \\
\hline Public Sector & 2.9 & 22.6 & 52.1 & 16.5 & 6.0 & 592 \\
\hline Manufacturing & 10.1 & 22.8 & 42.0 & 18.7 & 6.3 & 482 \\
\hline Private Services & 3.0 & 20.3 & 48.3 & 18.5 & 9.9 & 702 \\
\hline Public Services & 2.2 & 22.6 & 52.7 & 16.5 & 5.9 & 530 \\
\hline Union & 5.1 & 22.4 & 48.6 & 16.9 & 6.8 & 1,193 \\
\hline Non-union & 5.7 & 19.3 & 43.7 & 21.3 & 10.0 & 669 \\
\hline Private-Union & 6.9 & 22.4 & 45.8 & 17.4 & 7.5 & 637 \\
\hline Private-Nonunion & 6.1 & 19.0 & 43.1 & 21.5 & 10.3 & 633 \\
\hline \multicolumn{7}{|c|}{1984} \\
\hline All Establishments & 4.7 & 19.2 & 48.9 & 19.0 & 8.3 & 1,862 \\
\hline Private Sector & 5.7 & 18.5 & 42.9 & 21.5 & 11.3 & 1,199 \\
\hline Public Sector & 2.8 & 20.4 & 59.6 & 14.4 & 2.8 & 663 \\
\hline Manufacturing & 7.5 & 20.2 & 38.5 & 23.8 & 10.0 & 410 \\
\hline Private Services & 4.1 & 19.0 & 45.7 & 20.9 & 10.2 & 716 \\
\hline Public Services & 2.7 & 19.9 & 60.8 & 13.6 & 3.0 & 613 \\
\hline Union & 5.4 & 20.9 & 51.6 & 16.6 & 5.6 & 1,240 \\
\hline Non-union & 3.2 & 15.7 & 43.4 & 23.8 & 13.7 & 622 \\
\hline Private-Union & 8.2 & 21.1 & 42.7 & 18.8 & 9.1 & 588 \\
\hline Private-Nonunion & 3.3 & 16.0 & 43.1 & 24.1 & 13.4 & 611 \\
\hline \multicolumn{7}{|c|}{1990} \\
\hline All Establishments & 5.3 & 16.4 & 44.9 & 22.1 & 11.3 & 1,766 \\
\hline Private Sector & 6.1 & 17.7 & 38.3 & 24.0 & 13.9 & 1,255 \\
\hline Public Sector & 3.2 & 13.2 & 61.1 & 17.5 & 5.0 & 511 \\
\hline Manufacturing & 7.4 & 23.0 & 38.7 & 19.7 & 11.2 & 403 \\
\hline Private Services & 5.2 & 15.2 & 36.4 & 27.5 & 15.7 & 771 \\
\hline Public Services & 3.1 & 12.1 & 61.9 & 17.8 & 5.1 & 499 \\
\hline Union & 4.3 & 16.5 & 52.3 & 18.9 & 7.9 & 898 \\
\hline Nonunion & 6.3 & 16.3 & 37.2 & 25.4 & 14.8 & 868 \\
\hline Private-Union & 5.6 & 19.4 & 45.3 & 19.5 & 10.3 & 458 \\
\hline Private-Nonunion & 6.4 & 16.7 & 34.2 & 26.6 & 16.0 & 797 \\
\hline
\end{tabular}

Base: All establishments reporting employment at the time of the survey and one year earlier.

Source: Workplace Industrial Relations Surveys (1980, 1984, and 1990).

The 1990 survey reports employment in $1990,1989,1987$, and 1984 , so an interesting exercise is to compare the performance of establishments that were in existence at all these dates over the two three-year spells 1984-87 and 1987-90. Table 5 reports the results. Before considering the data, note that the bias introduced by the sample selection procedure will be particularly noticeable here. Of establishments in which employment fell by $20 \%$ or more over the first period, presumably many would have continued to decline over the second; however, many of those will not be in the sample.
Thus, particularly in the first row, there is an artificial inflation of the data in the right-hand cells.

Once again the data are weighted using the 1990 weights, although we do report the unweighted bases. Approximately a quarter of establishments that declined by at least one-fifth between 1984 and 1987 declined by a further $20 \%$ over the following three-year period. However, a further quarter grew by at least $20 \%$ over the later period. Of the establishments that grew by at least $20 \%$ in the first period, approximately one-half had similar growth pat- 
Table 4. Employment Growth by Base Year Plant Size.

\begin{tabular}{|c|c|c|c|c|c|c|c|c|}
\hline \multirow{2}{*}{$\begin{array}{l}\text { Base Year } \\
\text { Plant Size }\end{array}$} & \multicolumn{5}{|c|}{ Growth Rate (\%) } & \multirow{2}{*}{$\begin{array}{c}\text { Mean } \\
\text { Growth } \\
\text { Rate \% }\end{array}$} & \multirow[b]{2}{*}{$\begin{array}{c}\text { Weighted } \\
\text { Base }\end{array}$} & \multirow[b]{2}{*}{$\begin{array}{c}\text { Unweighted } \\
\text { Base }\end{array}$} \\
\hline & $\leq-20$ & $>-20 \mathcal{E} \leq-5$ & $-5<\varepsilon^{2}<5$ & $\geq 5 \mathcal{E}<20$ & $\geq 20$ & & & \\
\hline 1980: 1-Year & & & & & & & 1,862 & 1,886 \\
\hline$\leq 49$ & 5 & 20 & 46 & 19 & 11 & 4.41 & 937 & 345 \\
\hline$>49 \& \leq 99$ & 5 & 21 & 48 & 21 & 5 & 0.04 & 464 & 341 \\
\hline$>99 \& \leq 199$ & 7 & 26 & 44 & 18 & 5 & -1.88 & 258 & 372 \\
\hline$>199 \& \leq 499$ & 7 & 24 & 56 & 11 & 2 & -3.20 & 139 & 337 \\
\hline$>499 \& \leq 999$ & 8 & 19 & 52 & 18 & 3 & -2.94 & 39 & 241 \\
\hline$>999$ & 7 & 30 & 50 & 13 & 1 & -3.88 & 25 & 250 \\
\hline 1984: 1-Year & & & & & & & 1,862 & 1,813 \\
\hline$\leq 49$ & 3 & 20 & 47 & 20 & 10 & 4.31 & 972 & 328 \\
\hline$>49 \& \leq 99$ & 4 & 18 & 51 & 18 & 8 & 1.58 & 469 & 336 \\
\hline$>99 \& \leq 199$ & 8 & 17 & 50 & 18 & 8 & -0.14 & 242 & 338 \\
\hline$>199 \& \leq 499$ & 8 & 22 & 51 & 18 & 1 & -3.03 & 121 & 301 \\
\hline$>499 \& \leq 999$ & 10 & 18 & 52 & 18 & 2 & -5.23 & 37 & 251 \\
\hline$>999$ & 5 & 26 & 58 & 10 & 1 & -3.97 & 21 & 259 \\
\hline 1990: 1-Year & & & & & & & 1,766 & 1,705 \\
\hline$\leq 49$ & 2 & 14 & 46 & 26 & 13 & 6.95 & 943 & 312 \\
\hline$>49 \& \leq 99$ & 9 & 19 & 44 & 17 & 10 & 0.59 & 466 & 318 \\
\hline$>99 \& \leq 199$ & 8 & 21 & 44 & 17 & 10 & 0.13 & 210 & 294 \\
\hline$>199 \& \leq 499$ & 7 & 18 & 46 & 23 & 6 & -0.39 & 108 & 287 \\
\hline$>499 \& \leq 999$ & 4 & 22 & 57 & 14 & 2 & -1.72 & 26 & 195 \\
\hline$>999$ & 8 & 19 & 53 & 14 & 6 & -3.40 & 14 & 299 \\
\hline
\end{tabular}

Base: All establishments reporting employment at the time of the survey and one year earlier.

Source: Workplace Industrial Relations Surveys $(1980,1984$, and 1990).

terns in the second period. These data appear to reflect persistence more than mean reversion. Mean reversion would be indicated by weight on the diagonal running from upper right to lower left, whereas most of the weight is actually around the main (upper left to lower right) diagonal. Thus a broad generalization is that establishments will typically continue to grow or decline rather than fluctuate around a particular employment level. This pattern is in line with the persistence results of Davis and Haltiwanger (1992).

Table 5. Persistence of Plant Level Employment Growth.

\begin{tabular}{lccccrr}
\hline & \multicolumn{5}{c}{ Growth Rate, 1987-1990(\%) } \\
\cline { 2 - 5 } $\begin{array}{l}\text { Growth Rate, } \\
1984-1987(\%)\end{array}$ & $\leq-20$ & $>-20 \mathcal{E}^{2} \leq-5$ & $-5<\mathcal{E}<+5$ & $\geq 5 \mathcal{E}^{2}<20$ & $\geq+20$ & Unweighted Base \\
\hline$\leq-20$ & 27 & 22 & 14 & 13 & 25 & 93 \\
$-20 \leq \&<-5$ & 20 & 39 & 21 & 14 & 6 & 221 \\
$-5<\&<+5$ & 11 & 23 & 35 & 21 & 10 & 352 \\
$+5 \leq \&<+20$ & 6 & 13 & 23 & 33 & 24 & 278 \\
$\geq+20$ & 8 & 13 & 9 & 21 & 49 & 246 \\
These are row percentages & & & & & & 1,190 \\
\hline
\end{tabular}

Notes: weighted by 1990 weights.

Base: All establishments reporting employment at the time of the survey and three years earlier.

Source: Workplace Industrial Relations Survey (1990). 
Table 6. Job Creation and Destruction by Sector: Totals.

\begin{tabular}{|c|c|c|c|c|c|c|}
\hline \multirow[b]{2}{*}{ Year } & \multicolumn{4}{|c|}{ Sector } & \multirow[b]{2}{*}{$\begin{array}{c}\text { Number } \\
\text { of Jobs }\end{array}$} & \multirow[b]{2}{*}{$\begin{array}{c}\text { Weighted } \\
\text { Number of } \\
\text { Establishments }\end{array}$} \\
\hline & $\begin{array}{c}\text { Private } \\
\text { Manufacturing }\end{array}$ & $\begin{array}{c}\text { Private } \\
\text { Non- } \\
\text { Manufacturing }\end{array}$ & $\begin{array}{l}\text { Public } \\
\text { Sector }\end{array}$ & $\begin{array}{l}\text { Union } \\
\text { Sector }\end{array}$ & & \\
\hline \multicolumn{7}{|c|}{ (a) $\%$ of JC } \\
\hline 1980 & 28 & 39 & 32 & 70 & 7,922 & 755 \\
\hline 1984 & 33 & 43 & 24 & 65 & 7,387 & 789 \\
\hline 1990 & 27 & 48 & 25 & 54 & 9,262 & 845 \\
\hline \multicolumn{7}{|c|}{ (b) \% of JD } \\
\hline 1980 & 58 & 20 & 22 & 80 & 11,449 & 760 \\
\hline 1984 & 45 & 27 & 28 & 89 & 10,351 & 745 \\
\hline 1990 & 30 & 35 & 35 & 68 & 9,034 & 604 \\
\hline \multicolumn{7}{|c|}{ (c) \% Employment } \\
\hline 1980 & 41 & 25 & 34 & 80 & 221,002 & 1,862 \\
\hline 1984 & 30 & 29 & 41 & 80 & 200,053 & 1,862 \\
\hline 1990 & 29 & 37 & 34 & 66 & 170,067 & 1,766 \\
\hline
\end{tabular}

Base: All establishments reporting employment at the time of the survey and one year earlier. Weighted data. Source: Workplace Industrial Relations Surveys (1980, 1984, and 1990).

\section{Job Creation and Job Destruction}

Although we only have three cross-sections, they are from interesting and quite different years: in 1980 the first dramatic rise in unemployment began, in 1984 the rise in unemployment flattened out, and in 1990 unemployment fell quite substantially. As can be seen from columns 5 and 6 of Table 6, which reports one-year changes, 9,300 jobs were created in the WIRS3 data file for the period $1989 / 90$, and 9,000 jobs were destroyed. The numbers in the previous years were 7,900 created and 11,400 destroyed in 1979/80 (WIRS1) and 7,500 created and 10,300 destroyed in 1983/84 (WIRS2). These numbers imply that across the entire population of surviving establishments with at least 25 employees in $1990,702,150$ jobs were created and 679,500 were destroyed between 1989 and 1990. In 1984 fewer jobs were created $(512,250)$, but roughly the same number were destroyed $(703,490)$.

Table 6 also shows that manufacturing accounted for a reasonable share of job creation even in 1980 and 1984. Because of the higher employment growth variance and larger establishment size in manufacturing, a given mean growth rate implies greater job creation in that sector than in non-manufacturing. The table also shows the extent to which job destruction in 1980 and 1984 was centered on manufacturing: $58 \%$ of jobs destroyed were in manufacturing in 1980, compared with $30 \%$ in 1990 . In 1980 private manufacturing accounted for $41 \%$ of employment in the WIRS1 sample, compared with $29 \%$ of total employment in 1990 (Panel 3 of Table 6). Private nonmanufacturing was responsible for $35 \%$ of job creation in 1990, compared with $20 \%$ in 1980. The public sector accounted for a smaller proportion of job creation and a higher proportion of job destruction at the end of the period than at the beginning. The decline in the size of the union sector that occurred during the $1980 \mathrm{~s}$ is reflected here in a decline in its contribution to both job creation and job destruction.

Also illuminating is the concentration of job creation and destruction across establishments. In our dataset these processes are extremely concentrated, as shown graphically by the Lorenz curves in Figures $1 \mathrm{a}$ and $1 \mathrm{~b}$. In each of the three years, approximately $50 \%$ of all jobs created are accounted for by around $10 \%$ of growing establishments (Figure 1a), and $50 \%$ of all jobs destroyed are accounted for by about 
$10 \%$ of declining establishments (Figure 1b). Therefore, since, on average over the three years, $43.6 \%$ of establishments were hiring, we can say that $50 \%$ of all jobs created were accounted for by about $4 \%$ of establishments. Similarly, $50 \%$ of all jobs destroyed in surviving establishments were accounted for by $4 \%$ of establishments.

Manufacturing plants are well represented among the big job-creators (the top decile): $32 \%$ of plants in the top JC decile in 1990 were in manufacturing. Manufacturing plants are also predominant among the top decile of job destroyers. In 1980, in particular, $65 \%$ of plants in that decile were in manufacturing; by 1990, however, the percentage was down to $40 \%$.

The average (absolute) growth rate increases by decile for both JC and JD. This relationship is not tautological, and indeed the reverse could easily be true. Another way of looking at this is to compute shares of jobs created (destroyed) by growth rate. In fact, less than half of all jobs created (destroyed) came from fast-growing (declining) plants (defined as having an absolute growth rate in excess of $20 \%$ ), and about a third came from relatively slow growers $(0-10 \%)$. This concentration is not necessarily due to differences in establishment size. Clearly, JC and JD are related to establishment size: a $1 \%$ growth rate leads to more jobs being created in an establishment with 10,000 employees than it does in one with 100 employees. We find that average establishment size by JC or JD decile increases slowly up to the 9 th decile, and the final decile contains significantly larger establishments. ${ }^{10}$ However, this fact does not explain away the concentration: it would be perfectly possible for the existing size distribution to coexist with a much less concentrated distribution of JC\&JD.

Two further patterns we find are (a) a very similar degree of concentration across the three years, although JD is less concen-

\footnotetext{
${ }^{10}$ For example, the average size of plants in $1990 \mathrm{in}$ the top decile of JC (JD) is $306(405)$, while average size in the decile below is $132(137)$.
}

trated in 1980, and (b) a slightly higher concentration of JD than of JC in each year.

In Table 7, rather than report numbers of jobs created or destroyed, we report job creation and job destruction rates by sector. Following Davis and Haltiwanger (1990), " we define them as follows:

$$
\begin{gathered}
\text { JC rate }=\frac{\sum_{+}\left(N_{t}-N_{t-1}\right)}{\sum N_{t-1}}, \\
\text { JD rate }=\frac{\sum\left(N_{t}-N_{t-1}\right)}{\sum N_{t-1}},
\end{gathered}
$$

where the sum over "+" indicates the sum over growing establishments, the sum over "-" indicates the sum over declining establishments, and the sum in the denominator is the sum over all establishments. As mentioned above, these are two statistics based on the employment growth distribution that give us more information than can be gained from simply looking at the mean or variance. Furthermore, they are economically meaningful concepts, and their study has engendered considerable empirical and theoretical research (some of it discussed in the Data section above).

The overall job creation rate rose from 3.58 in $1979 / 80$ to 5.45 in 1989/90. Moreover, the job creation rate in every sector was higher at the end of the 1980s than it was at the beginning. It was lower in private manufacturing than in private non-manufacturing, and lower in the union sector than in the nonunion sector. The job destruction rate actually increased over the

\footnotetext{
"In fact, Davis and Haltiwanger divided by the average of current and lagged employment to cope with new plants for which $N t_{-1}$ is zero. As we do not have that problem, we simply divide by lagged employment. This means that the job creation and destruction rates reported here will be slightly larger than they would be if we followed the DavisHaltiwanger convention. On the other hand, of course, our measures of job flows will be lower than they are in studies that can include births and deaths of firms. The two measures are monotonically related.
} 
Figure 1a. Concentration of Job Creation, 1980, 1984, and 1990.

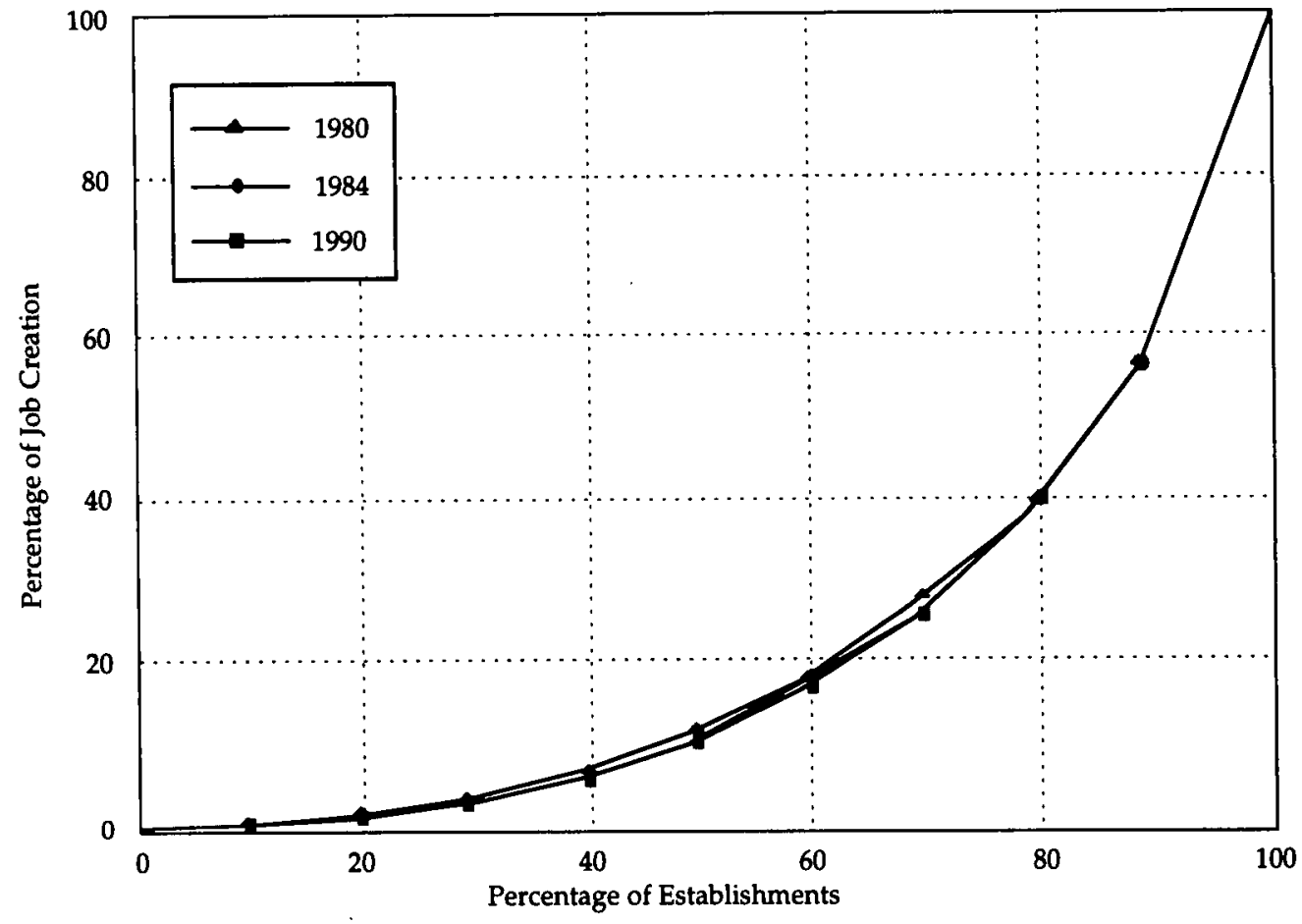

Figure 1b. Concentration of Job Destruction, 1980, 1984, and 1990.

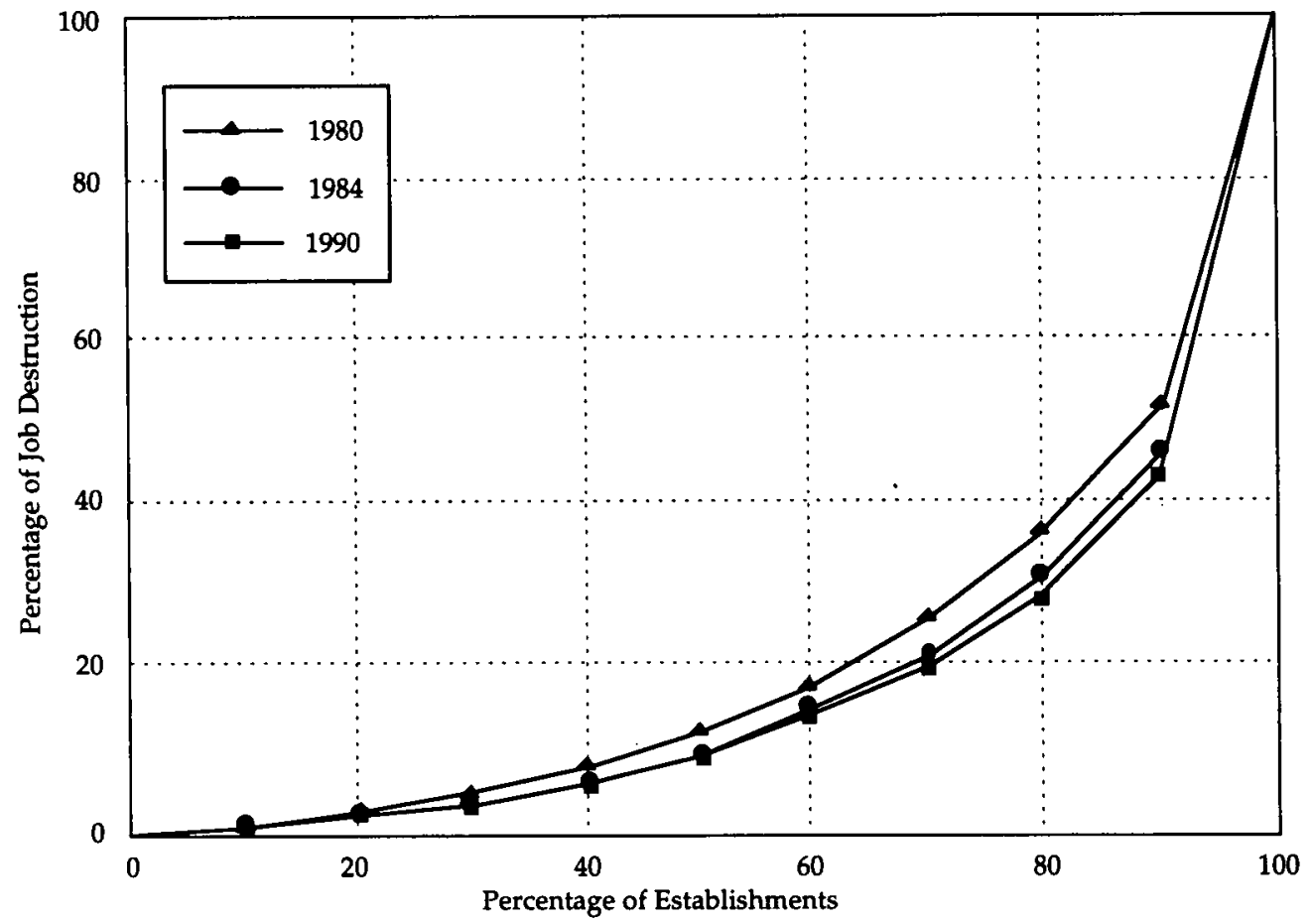


Table 7. Job Creation and Destruction Rates by Sector.

\begin{tabular}{lcccccccc}
\hline & $\begin{array}{c}\text { Private } \\
\text { Manu- } \\
\text { facturing }\end{array}$ & $\begin{array}{c}\text { Private } \\
\text { Services }\end{array}$ & $\begin{array}{c}\text { Private } \\
\text { Sector }\end{array}$ & $\begin{array}{c}\text { Public } \\
\text { Sector }\end{array}$ & $\begin{array}{c}\text { Union } \\
\text { Sector }\end{array}$ & $\begin{array}{c}\text { Nonunion } \\
\text { Sector }\end{array}$ & $\begin{array}{c}\text { Weighted } \\
\text { Number of } \\
\text { Overall Establishments }\end{array}$ \\
\hline $\begin{array}{l}\text { (a) JC Rate } \\
1980\end{array}$ & & & & & & & & \\
1984 & 2.48 & 5.18 & 3.71 & 3.56 & 3.12 & 5.48 & 3.58 & 755 \\
1990 & 3.92 & 4.82 & 4.73 & 2.35 & 3.00 & 6.46 & 3.69 & 789 \\
(b) JD Rate & 5.02 & 7.43 & 6.21 & 3.97 & 4.44 & 7.41 & 5.45 & 845 \\
1980 & & & & & & & & \\
1984 & 7.25 & 3.79 & 6.20 & 2.50 & 5.19 & 5.15 & 5.18 & 760 \\
1990 & 7.94 & 4.26 & 6.33 & 3.16 & 5.74 & 2.91 & 5.17 & 745 \\
\hline
\end{tabular}

Note: These are weighted (Davis-Haltiwanger) rates.

Base: All establishments reporting employment at the time of the survey and one year earlier.

Source: Workplace Industrial Relations Surveys (1980, 1984, and 1990).

period. It declined in private manufacturing but increased strongly in both private services and the public sector. The union sector showed a small increase in the JD rate over the period, while the nonunion sector experienced a small decrease.

In Tables 8-10 we explore further the differences in job creation and destruction rates. Table 8 reports the distribution of JC\&D by base year establishment size. There seems to be a natural watershed around a size of 200. Below that size, establishments tend to create more than their "share" of jobs; above it, they destroy more than their share of jobs. We illustrate this in columns 5 and 6 of the table, where we divide the shares of JC and JD, respectively, by the share of employment reported in column 3 . Within the context of the selection of our sample of continuing establishments, medium to large establishments (those with 100 or more employees) account for over $50 \%$ of jobs created. This finding runs counter to existing wisdom on the importance of small firms, but comports with the most recent work of Davis, Haltiwanger, and Schuh (1994).

Table 9 examines differences in oneyear job creation and destruction rates between union and nonunion workplaces in the private sector. Because union workplaces tend to be larger than nonunion workplaces, we produce separate estimates for big and small workplaces, with $200 \mathrm{em}$ - ployees taken as the cut-off. In the first two columns of the table we report actual numbers of jobs created (JC) and destroyed (JD) for the periods $1979 / 80,1983 / 84$, and 1989/90. Columns 3 and 4 show job creation and job destruction rates; columns 5 and 6 show the proportion of establishments that expanded and declined, respectively, over the relevant period; and columns 7-9 report total employment, the number of establishments (weighted), and the average size of establishments in the base year.

Several patterns are apparent. First, at the beginning of the $1980 \mathrm{~s}, 72 \%$ of private sector workers in our sample were members of unions, compared with $52.3 \%$ at the end. Second, the share of employment accounted for by workers in "big" union workplaces fell from $47 \%$ to $30 \%$. The share of small union workplaces fell only slightly, from $25 \%$ to $23 \%$. Third, the average size of big union workplaces also declined during the $1980 \mathrm{~s}$-from $655 \mathrm{em}$ ployees in 1979 to 488 employees in 1989 while the small number of big nonunion establishments in the sample increased their average size from 373 to 397 . Fourth, the average size of both small union and small nonunion workplaces remained roughly constant. Fifth, job creation rates tended to be highest in all periods in small nonunion establishments. Sixth, in 1979/80 the union sector created more jobs than 
Table 8. Job Creation and Destruction by Establishment Size.

\begin{tabular}{|c|c|c|c|c|c|c|}
\hline $\begin{array}{l}\text { Establishment } \\
\text { Size }\end{array}$ & $\begin{array}{c}\text { Share } \\
\text { of JC } \\
(1)\end{array}$ & $\begin{array}{l}\text { Share } \\
\text { of } J D \\
(2)\end{array}$ & $\begin{array}{c}\text { Share of } \\
\text { Employment } \\
\text { (3) }\end{array}$ & $\begin{array}{c}\text { Share of } \\
\text { Establishments } \\
\text { (4) }\end{array}$ & $(1) /(3)$ & $(2) /(3)$ \\
\hline \multicolumn{7}{|l|}{1980} \\
\hline$\leq 49$ & 27 & 10 & 15 & 50 & 1.9 & 0.7 \\
\hline$>49 \& \leq \leq 99$ & 17 & 11 & 14 & 25 & 1.2 & 0.8 \\
\hline$>99 \& \leq 199$ & 19 & 19 & 16 & 14 & 1.2 & 1.4 \\
\hline$>199 \& \leq 499$ & 11 & 21 & 19 & 7 & 0.6 & 1.1 \\
\hline$>499 \& \leq 999$ & 11 & 15 & 13 & 2 & 0.9 & 1.1 \\
\hline$>999$ & 14 & 23 & 23 & 1 & 0.6 & 1.0 \\
\hline \multicolumn{7}{|l|}{1984} \\
\hline$\leq 49$ & 28 & 12 & 17 & 52 & 1.6 & 0.7 \\
\hline$>49 \& \leq 99$ & 20 & 10 & 16 & 25 & 1.3 & 0.6 \\
\hline$>99 \& \leq \leq 199$ & 21 & 16 & 17 & 13 & 1.3 & 0.9 \\
\hline$>199 \& \leq 499$ & $\cdot 14$ & 21 & 18 & 6 & 0.8 & 1.1 \\
\hline$>499 \& \leq 999$ & 8 & 20 & 12 & 2 & 0.6 & 1.6 \\
\hline$>999$ & 8 & 22 & 20 & 1 & 0.4 & 1.1 \\
\hline \multicolumn{7}{|l|}{1990} \\
\hline$\leq 49$ & 27 & 9 & 19 & 53 & 1.4 & 0.5 \\
\hline$>49 \& \leq \leq 9$ & 21 & 19 & 18 & 26 & 1.1 & 1.0 \\
\hline$>99 \&<\leq 199$ & 18 & 18 & 17 & 12 & 1.1 & 1.1 \\
\hline$>199 \& \leq 499$ & 18 & 22 & 19 & 6 & 0.9 & 1.1 \\
\hline$>499 \& \leq 999$ & 6 & 9 & 10 & 1 & 0.6 & 0.9 \\
\hline$>999$ & 10 & 21 & 15 & 1 & 0.7 & 1.4 \\
\hline
\end{tabular}

Note: Plant size is reported as the base year, so for 1980 it is 1979 employment and so on.

Base: All establishments reporting employment at the time of the survey and one year earlier.

Source: Workplace Industrial Relations Surveys (1980, 1984, and 1990).

the nonunion sector; by $1989 / 90$ the picture was reversed. Seventh, job destruction rates also tended to be highest in all periods in small nonunion establishments, but by the end of the 1980 s nonunion establishments were responsible for a much higher share $(47 \%)$ than they were at the beginning of the decade $(24 \%)$.

In Table 10, we look at the age of operation of establishments. At the outset, we should note that in 1990 the question asked was "For how long has this establishment been operating here at this address?" whereas in the previous two years it was "How long ago did the establishment first engage in its main activity?" The distribution of employment in column 3 suggests that the difference matters, so 1990 is not strictly comparable.

There is evidence in column 4 of a strong negative relationship between employment growth and the age of an establishment across all years. We also find a strong negative relationship in 1980 and 1984 between the age of the establishment and the job creation rate: among establishments less than three years old in 1980 , the job creation rate was $19.2 \%$ in 1980 and $15.7 \%$ in 1984, whereas among those that were at least 25 years old in 1980 , the corresponding figures were $2.6 \%$ and $5.4 \%$. By 1990 the relationship was a good deal weaker.

There is much less evidence of a high degree of correlation between age and the job destruction rate. It is worth emphasizing, however, that even among long-lived establishments, there is appreciable job creation and destruction. Clearly, there is a strong correlation between age and size, and, as might be expected, older (hence bigger) continuing workplaces account for a large proportion of jobs created and destroyed. 
Table 9. Job Creation and Job Destruction: Private Sector Union and Nonunion Establishments.

\begin{tabular}{|c|c|c|c|c|c|c|c|c|c|}
\hline Type of Establishment & $\begin{array}{l}\text { Total } \\
J C \\
(I)\end{array}$ & $\begin{array}{l}\text { Total } \\
J D \\
(2)\end{array}$ & $\begin{array}{c}J C \\
\text { Rate } \\
(3)\end{array}$ & $\begin{array}{c}J D \\
\text { Rate } \\
(4)\end{array}$ & $\begin{array}{c}\% \\
\text { Growing } \\
\text { (5) }\end{array}$ & $\begin{array}{c}\% \\
\text { Declining } \\
(6)\end{array}$ & $\begin{array}{l}\text { Total } \\
\text { Empt. } \\
\text { (7) }\end{array}$ & $\begin{array}{c}\text { No. of } \\
\text { Estabs. } \\
\text { (8) }\end{array}$ & $\begin{array}{c}\text { Avg. } \\
\text { Size } \\
\text { (9) }\end{array}$ \\
\hline \multicolumn{10}{|c|}{1980} \\
\hline BIG: Union & 1468 & 4,458 & 2.2 & 6.6 & 33.9 & 64.2 & 67,458 & 103 & 655 \\
\hline BIG: Nonunion & 325 & 807 & 3.6 & 9.0 & 43.4 & 44.7 & 8,943 & 24 & 373 \\
\hline SMALL: Union & 1,634 & 2,321 & 4.5 & 6.4 & 39.2 & 43.0 & 36,422 & 535 & 68 \\
\hline SMALL: Nonunion & 1,944 & 1,394 & 6.1 & 4.3 & 44.1 & 33.8 & 32,015 & 609 & 52 \\
\hline \multicolumn{10}{|c|}{1984} \\
\hline BIG: Union & 1,010 & 4,535 & 2.2 & 10.1 & 32.5 & 64.1 & 44,956 & 75 & 599 \\
\hline BIG: Nonunion & 362 & 197 & 4.3 & 2.4 & 55.7 & 39.5 & 8,344 & 21 & 397 \\
\hline SMALL: Union & 2,021 & 1,779 & 6.0 & 5.3 & 42.5 & 42.2 & 33,560 & 512 & 65 \\
\hline SMALL: Nonunion & 2,199 & 971 & 7.0 & 3.1 & 52.4 & 30.1 & 31,284 & 591 & 53 \\
\hline \multicolumn{10}{|c|}{1990} \\
\hline BIG: Union & 1,254 & 1,861 & 3.8 & 5.6 & 42.8 & 52.2 & 33,163 & 68 & 488 \\
\hline BIG: Nonunion & 843 & 479 & 7.6 & 4.3 & 54.9 & 39.4 & 11,106 & 28 & 397 \\
\hline SMALL: Union & 1,570 & 1,277 & 6.1 & 5.0 & 45.5 & 40.5 & 25,522 & 390 & 65 \\
\hline SMALL: Nonunion & 3,303 & 2,263 & 7.8 & 5.3 & 53.0 & 32.6 & 42,404 & 769 & 55 \\
\hline
\end{tabular}

Note: All private sector establishments. Big (small) means more than 200 (200 or less). This refers to initial year (for example, 1979 for 1980).

JC \& JD Rates are calculated as the size-weighted means of the growth rates (Davis-Haltiwanger) in the relevant category.

Base: All establishments reporting employment at the time of the survey and one year earlier.

Source: Workplace Industrial Relations Surveys (1980, 1984, and 1990).

\section{Job Reallocation}

We now examine the difference in the job reallocation rate (JR) by sector and over time. We define this difference as the sum of the job creation and job destruction rates defined above; it is thus a measure of the total job mobility in a sector. The large magnitude of job reallocation we demonstrate indicates a high degree of heterogeneity in employment growth. Differences in the job reallocation rate between sectors in the United States have been studied by Davis and Haltiwanger (1992), Davis, Haltiwanger, and Schuh (1994), and OECD (1994).

As can be seen from Table 11, the job reallocation rate increased over the three years (averages are 8.76 in $1980,8.86$ in 1984 , and 10.76 in 1990). Moreover, the increase in the JR rate occurred principally outside private manufacturing: the JR rate increased in private services and the public sector by over a third between the beginning and the end of the decade. There were also increases through time in the JR rate in both the union and nonunion sectors, with the amount of job reallocation always higher in the nonunion sector. Both small union and small nonunion establishments in the private sector experienced increases in the JR rate. Big union establishments also experienced increases, but big nonunion establishments experienced a decrease. The table shows clearly that the private sector generates more job reallocation than does the public sector and that the nonunion sector generates more than the union sector.

In line with the rest of this literature, all of the above analysis uses unconditional, bivariate tabulations. That is, in examining the effect of unionization on, for example, the JR rate, we do not hold constant size, industry, or other factors. The reason we do not include such controls is that there is no systematic method, to our knowledge, for determining exactly what sort of multivariate regression is appropriate. The JC and JD rates are properties of aggregates, 
Table 10. Job Creation and Destruction by Age of Establishment.

\begin{tabular}{|c|c|c|c|c|c|c|c|}
\hline \multirow[b]{2}{*}{ Age (years) } & \multicolumn{7}{|c|}{ Share of Total (\%) } \\
\hline & $\begin{array}{c}J C \\
(\% \text { Share } \\
\text { of Total) }\end{array}$ & $\begin{array}{c}J D \\
(\% \text { Share } \\
\text { of Total) }\end{array}$ & $\begin{array}{c}\text { Employment } \\
\text { (\% Share } \\
\text { of Total) }\end{array}$ & $\begin{array}{l}\text { Employment } \\
\text { Growth Rate } \\
\quad(\%)\end{array}$ & $\begin{array}{c}J C \\
\text { Rate } \\
(\%)\end{array}$ & $\begin{array}{l}J D \\
\text { Rate } \\
(\%)\end{array}$ & $\begin{array}{c}\text { Weighted } \\
\text { No. } \\
\text { of Estabs. }\end{array}$ \\
\hline \multicolumn{8}{|c|}{1980} \\
\hline$<3$ & 5 & 0 & 1 & 23.5 & 19.2 & 2.9 & 27 \\
\hline$\geq 3 \&<5$ & 4 & 4 & 3 & 0.26 & 5.3 & 8.7 & 50 \\
\hline$\geq 5 \& c<10$ & 15 & 8 & 10 & 4.88 & 5.5 & 4.8 & 158 \\
\hline$\geq 11 \&<25$ & 32 & 25 & 25 & 2.24 & 4.9 & 6.4 & 333 \\
\hline$\geq 25$ & 43 & 63 & 62 & -1.07 & 2.6 & 6.4 & 656 \\
\hline TOTAL & 5,248 & 8,856 & 141,422 & 1.40 & 3.7 & 6.3 & 1,270 \\
\hline \multicolumn{8}{|c|}{1984} \\
\hline$<3$ & 3 & 2 & 1 & 45.32 & 15.7 & 12.8 & 27 \\
\hline$\geq 3 \&<5$ & 5 & 1 & 4 & 4.92 & 8.0 & 3.1 & 59 \\
\hline$\geq 5 \&<10$ & 12 & 11 & 10 & 4.30 & 7.6 & 9.8 & 151 \\
\hline$\geq 11 \&<25$ & 31 & 20 & 28 & 2.65 & 7.0 & 6.3 & 342 \\
\hline$\geq 25$ & 48 & 65 & 56 & 1.51 & 5.4 & 10.1 & 591 \\
\hline TOTAL & 7,306 & 10,141 & 115,581 & 3.48 & 6.3 & 8.8 & 1,199 \\
\hline \multicolumn{8}{|c|}{1990} \\
\hline$<3$ & 8 & 7 & 6 & 7.09 & 8.6 & 6.3 & 90 \\
\hline$\geq 3 \&<5$ & 11 & 13 & 8 & 4.11 & 8.5 & 9.2 & 120 \\
\hline$\geq 5 \&<10$ & 21 & 13 & 13 & 9.19 & 10.5 & 5.4 & 206 \\
\hline$\geq 11 \&<25$ & 23 & 24 & 21 & 2.73 & 6.7 & 5.8 & 287 \\
\hline$\geq 25$ & 37 & 43 & 53 & 1.84 & 4.3 & 4.4 & 535 \\
\hline TOTAL & 6,816 & 5,846 & 110,716 & 3.86 & 6.2 & 5.3 & 1,255 \\
\hline
\end{tabular}

Notes: Note that in 1990 the question asked was "For how long has this establishment been operating here at this address?" whereas in the previous two years it was "How long ago did the establishment first engage in its main activity?" From the distribution of employment, it seems that the difference matters, so 1990 is not strictly comparable.

Employment growth calculated as follows: $\frac{N_{t}-N_{t-1}}{N_{t-1}} * 100$ with the weights applied. Private sector only.

Base: All establishments reporting employment at the time of the survey and one year earlier.

Source: Workplace Industrial Relations Surveys (1980, 1984, and 1990).

not individual establishments, as of course are measures of dispersion. However, the approach we adopt is to use the absolute value of the growth rate as a dependent variable. This is the establishment level analog of the aggregate job reallocation rate. High values of the dependent variable will be associated with features that produce both high positive and high negative growth rates. Features that affect the first moment of the employment growth distribution should generally not have a significant effect on the absolute growth rate.

In Table 12 we report the results of running a series of unweighted regressions with the absolute value of the one-year growth rate as the dependent variable. We pool the data from all three of our surveys for private sector establishments only (yielding in total of 3,615 observations). We include as explanatory variables year dummies, industry dummies, the lagged employment level (measuring base year size), age of operation, whether the establishment was a single independent organization, union status, and a set of variables reflecting the demand conditions experienced by the establishment over the year preceding the interview date. In reading the table, note that in column 1 only year dummies are included, and as we move to the right from column 2 to column 5 , lagged employment, industry dummies, age of 
operation dummies, and demand dummies are added in turn. In columns 6-8, separate results are presented from each of the three WIRS surveys.

Job reallocation in 1984 is indistinguishable from that in 1980 , but 1990 yields a significantly higher number, confirming the results in the final row of Table 11. The negative coefficient on the lagged employment level supports the general idea that job turnover is lower among bigger establishments, but again, this is now confirmed in a multivariate context. In column 4 the age variables are strongly significant and suggest that the job reallocation rate declines with workplace age, holding constant size in the base year. Establishments at least 25 years old have a particularly low $\mathrm{JR}$ rate; this is true in all years (see columns 6-8), despite some differences (as discussed above) between the 1990 survey and the surveys for the two earlier years in the wording of the questions on age.

Union recognition does not appear to significantly affect job turnover. This result disagrees with the established evidence that unions affect the mean employment growth rate. ${ }^{12}$ In columns 5 through 8 of Table 12, three dummy variables are included to control for the state of demand in the establishment's main product market over the preceding year. ${ }^{13}$ The inclusion of these variables has little effect. One exception is in 1980, when the demand down variable significantly raises the $\mathrm{JR}$ rate (presumably, reduces the negative growth rates).

\footnotetext{
1'See, for example, Blanchflower, Millward, and Oswald (1991), Leonard (1992), and Long (1993).

${ }^{19}$ The main management respondent at each workplace was asked, "Over the past twelve months would you say that demand for the main products or services of this establishment has been rising, falling, neither, or don't know?" The weighted proportions of responses in each category by year were as follows:
}

\begin{tabular}{lrrr} 
& 1980 & 1984 & 1990 \\
\hline Demand rising & 36.0 & 57.8 & 28.5 \\
Demand falling & 29.0 & 10.0 & 5.6 \\
Demand constant & 26.7 & 30.6 & 39.1 \\
Demand trend uncertain & 8.3 & 1.6 & 5.0 \\
\hline
\end{tabular}

Table 11. Job Reallocation Rate by Sector.

\begin{tabular}{|c|c|c|c|}
\hline Sector & $\begin{array}{r}1979 / \\
1980\end{array}$ & $\begin{array}{l}19831 \\
1984\end{array}$ & $\begin{array}{l}1989 / \\
1990\end{array}$ \\
\hline Private Manufacturing & 9.7 & 11.9 & 10.4 \\
\hline Private Services & 9.0 & 9.1 & 12.4 \\
\hline Private Sector & 9.9 & 11.1 & 11.5 \\
\hline Public Sector & 6.1 & 5.5 & 9.4 \\
\hline Union Sector & 8.3 & 8.7 & 9.9 \\
\hline Nonunion Sector & 10.6 & 9.4 & 12.4 \\
\hline Biga Union- & & & \\
\hline $\begin{array}{l}\text { Private Sector } \\
\text { Small }{ }^{\mathrm{b}} \text { Union- }\end{array}$ & 8.8 & 12.3 & 9.4 \\
\hline $\begin{array}{l}\text { Private Sector } \\
\text { Big Nonunion- }\end{array}$ & 10.9 & 11.3 & 11.1 \\
\hline $\begin{array}{l}\text { Private Sector } \\
\text { Small }{ }^{\mathrm{b}} \text { Nonunion- }\end{array}$ & 12.6 & 6.7 & 11.9 \\
\hline Private Sector & 10.4 & 10.1 & 13.1 \\
\hline $\begin{array}{l}<200 \text { Employees- } \\
\text { Private Sector } \\
\geq 200 \text { Employees- }\end{array}$ & 9.3 & 10.8 & 12.3 \\
\hline Private Sector & 10.7 & 10.7 & 10.2 \\
\hline Overall & 8.8 & 8.9 & 10.8 \\
\hline
\end{tabular}

"Big" defined as having at least 200 employees in the base year.

"Small" defined as having fewer than 200 employees in the base year.

Base: All establishments reporting employment at the time of the survey and one year earlier.

Source: Workplace Industrial Relations Surveys (1980, 1984, and 1990).

This significant result carries over to the pooled regression.

The single establishment dummy is also significant, indicating less job turnover among single establishments than among establishments that belong to multi-establishment firms. Note that in this regression context, these figures are now controlling for size of establishment, industry, and union status. Assuming that the other righthand-side variables control for most of the salient differences between establishments, this result provides the first evidence of how much of the measured JRR is due to a firm simply reallocating a given set of jobs between its various establishments. It seems that given an average absolute growth rate of $11.6 \%$, and a rate of (11.6-2.2)\% from column 5 of Table 12 for single independent establishments, $81 \%$ of the measured $\mathrm{JR}$ rate is "real" [((11.6-2.2)/11.6)*100]. 
Table 12. OLS Absolute Growth Rate Regressions.

\begin{tabular}{|c|c|c|c|c|c|c|c|c|}
\hline Independent Variable & (1) & (2) & (3) & (4) & (5) & $\begin{array}{c}(6) \\
1980\end{array}$ & $\begin{array}{c}(7) \\
1984\end{array}$ & $\begin{array}{c}(8) \\
1990\end{array}$ \\
\hline 1984 Dummy & $\begin{array}{r}0.547 \\
(0.76)\end{array}$ & $\begin{array}{c}0.489 \\
(0.69)\end{array}$ & $\begin{array}{c}0.593 \\
(0.84)\end{array}$ & $\begin{array}{c}0.454 \\
(0.64)\end{array}$ & $\begin{array}{r}0.762 \\
(1.03)\end{array}$ & N/A & $N / A$ & N/A \\
\hline 1990 Dummy & $\begin{array}{c}1.728^{*} \\
(2.47)\end{array}$ & $\begin{array}{l}1.746^{*} \\
(2.51)\end{array}$ & $\begin{array}{l}1.953^{* *} \\
(2.81)\end{array}$ & $\begin{array}{l}1.517^{*} \\
(2.18)\end{array}$ & $\begin{array}{l}2.313^{* *} \\
(3.01)\end{array}$ & $\mathrm{N} / \mathrm{A}$ & $N / A$ & $\mathrm{~N} / \mathrm{A}$ \\
\hline$E_{r-1}$ & & $\begin{array}{l}-1.168^{* *} \\
(5.41)\end{array}$ & $\begin{array}{l}-1.184^{* *} \\
(5.06)\end{array}$ & $\begin{array}{l}-1.103^{* *} \\
(4.36)\end{array}$ & $\begin{array}{l}-1.087^{* *} \\
(4.29)\end{array}$ & $\begin{array}{c}-.956^{*} \\
(2.20)\end{array}$ & $\begin{array}{l}-1.430^{* *} \\
(3.22)\end{array}$ & $\begin{array}{l}-0.925^{*} \\
(2.09)\end{array}$ \\
\hline Industry Dummies & No & No & 8 & 8 & 8 & 8 & 8 & 8 \\
\hline Single Independent & & & & $\begin{array}{l}-2.415^{* *} \\
(3.05)\end{array}$ & $\begin{array}{l}-2.176^{* *} \\
(2.72)\end{array}$ & $\begin{array}{c}-1.647 \\
(1.27)\end{array}$ & $\begin{array}{c}-3.422 * \\
(2.35)\end{array}$ & $\begin{array}{c}-2.343 \\
(1.58)\end{array}$ \\
\hline Age 3-5 Years & & & & $\begin{array}{l}-5.456^{* *} \\
(2.96)\end{array}$ & $\begin{array}{l}-5.446^{* *} \\
(2.95)\end{array}$ & $\begin{array}{c}-7.877 * \\
(2.08)\end{array}$ & $\begin{array}{c}-8.958^{*} \\
(2.47)\end{array}$ & $\begin{array}{c}-2.584 \\
(0.98)\end{array}$ \\
\hline Age 5-10 Years & & & & $\begin{array}{l}-5.937 * * \\
(3.88)\end{array}$ & $\begin{array}{l}-5.900^{* *} \\
(3.84)\end{array}$ & $\begin{array}{l}-9.207^{* *} \\
(3.20)\end{array}$ & $\begin{array}{l}-7.280^{*} \\
(2.49)\end{array}$ & $\begin{array}{c}-1.909 \\
(0.80)\end{array}$ \\
\hline Age 11-25 Years & & & & $\begin{array}{l}-7.739 * * \\
(5.55)\end{array}$ & $\begin{array}{l}-7.771 * * \\
(5.57)\end{array}$ & $\begin{array}{l}-9.319 * * \\
(3.53)\end{array}$ & $\begin{array}{l}-8.939 * * \\
(3.37)\end{array}$ & $\begin{array}{c}-5.144^{*} \\
(2.38)\end{array}$ \\
\hline Age 25 Years + & & & & $\begin{array}{l}-9.268^{* *} \\
(6.93)\end{array}$ & $\begin{array}{l}-9.287 * * \\
(6.94)\end{array}$ & $\begin{array}{c}-10.859 * * \\
(4.23)\end{array}$ & $\begin{array}{l}-8.117 * * \\
(3.14)\end{array}$ & $\begin{array}{c}-9.181^{* *} \\
(4.56)\end{array}$ \\
\hline Union Recognition & & & & $\begin{array}{l}-0.029 \\
(0.04)\end{array}$ & $\begin{array}{l}-0.026 \\
(0.04)\end{array}$ & $\begin{array}{r}0.247 \\
(0.21)\end{array}$ & $\begin{array}{c}0.918 \\
(0.78)\end{array}$ & $\begin{array}{l}-0.620 \\
(0.52)\end{array}$ \\
\hline Demand Up & & & & & $\begin{array}{r}1.152 \\
(1.66)\end{array}$ & $\begin{array}{c}1.920 \\
(1.48)\end{array}$ & $\begin{array}{r}.417 \\
(0.37)\end{array}$ & $\begin{array}{c}1.499 \\
(1.19)\end{array}$ \\
\hline Demand Down & & & & & $\begin{array}{l}2.321^{* *} \\
(2.65)\end{array}$ & $\begin{array}{l}2.794^{*} \\
(2.26)\end{array}$ & $\begin{array}{c}2.390 \\
(1.39)\end{array}$ & $\begin{array}{c}0.350 \\
(0.16)\end{array}$ \\
\hline $\begin{array}{l}\text { Demand Trend } \\
\text { Uncertain }\end{array}$ & & & & & $\begin{array}{l}.0274 \\
(0.02)\end{array}$ & $\begin{array}{r}.745 \\
(0.32)\end{array}$ & $\begin{array}{l}-2.548 \\
(0.65)\end{array}$ & $\begin{array}{c}2.680 \\
(0.43)\end{array}$ \\
\hline Constant & 10.090 & 16.227 & 15.081 & 23.865 & 22.802 & 22.478 & 23.682 & 25.908 \\
\hline$\underline{F}$ & 3.1796 & 11.884 & 9.877 & 10.618 & 9.426 & 3.675 & 4.894 & 5.010 \\
\hline $\bar{R}^{2}$ & .001 & .009 & .026 & .044 & .045 & .037 & .059 & .055 \\
\hline DF & 3612 & 3611 & 3603 & 3597 & 3594 & 1258 & 1121 & 1236 \\
\hline
\end{tabular}

Notes: Dependent variable is the absolute one-year growth rate (weighted mean 11.59: in 1980, 10.65; 1984, $11.62 ; 1990,12.51)$. T-statistics in parentheses. For an explanation of specification adjustments by column, see the text.

Base: All private sector establishments.

*Statistically significant at the .05 level; **at the .01 level (two-tailed tests).

Source: Workplace Industrial Relations Surveys (1980, 1984, and 1990).

\section{Discussion}

Our results shed important light on both the range and the diversity of establishment employment growth.

Range. Quite a large fraction of establishments experience substantial employment change over a year: in $1990,35 \%$ of surviving plants grew or declined by $10 \%$ a year or more; in 1984, $28 \%$ did; and in $1980,31 \%$ did. It seems unlikely that idiosyncratic plant-level wage changes can account for much of these large changes. Given estimated wage elasticities below unity, the required dispersion in real wage growth rates is not credible (see also Hamermesh 1993:155). More likely candidates as the driving force behind changes of this magnitude are two elements included in standard labor demand models but typically de-emphasized by them: idiosyncratic demand shocks and technological change. These employment growth rates can be viewed as the labor market consequences of various facets of product market competition: product and process innovation, new product diffusion processes, entry and exit, product life cycles, and so on. These 
factors influence the evolution of the firm's demand and output and hence employment; firms at different points in the lifecycle of a product face different employment growth distributions.

Diversity. The second feature we emphasize is differences in variability in employment growth between different sectors of the economy. For example, the higher variability among manufacturing establishments (plants) than among non-manufacturing establishments is surprising, because manufacturing plants are typically bigger than service establishments, and big establishments usually have lower rates of growth and decline. Furthermore, manufacturers can manage inventories to smooth production and employment, whereas service industries cannot. There may be a number of reasons for this result. One argument is that manufacturing markets are typically national or international in nature and more competitive. Small disturbances to demand or costs can therefore become magnified into large output and employment changes. Second, in manufacturing industry there is potentially more scope for introducing innovations in products and processes. These, too, will act to increase the variance of employment growth rates.

We also showed that half of all jobs created come from about $10 \%$ of growing establishments (4\% of all establishments). Included among these are large establishments growing moderately and mediumsized establishments growing rapidly; almost a third of them are in manufacturing. The same is true for job destruction, with a higher preponderance in manufacturing. This high concentration is difficult to explain in terms of conventional labor demand models. ${ }^{14}$ Rather, it seems to fit more comfortably with a more dynamic view of JC\&D, one that lays stress on, for example, firm (establishment) entry and exit and the growth and decline through the life cycle of a product, technology, or firm. Thus the major job creators are those hitting a "take-

\footnotetext{
${ }^{14}$ Of course, if we wrote $N^{d}=\alpha-\beta . w+\varepsilon$, we could trivially assign desired properties to $\varepsilon$.
}

off" phase of their life-cycle, and other job creators are progressing through "normal growth." A similar story could be told about job destruction.

How can all the facts established here and elsewhere in the JC\&D literature best be explained? We believe that approaches based either on a conventional labor demand model or a simple sectoral flows model can provide only limited insight on the diversity and concentration of growth rates. The selection and passive learning model of Jovanovic (1982) seems more promising, but Davis and Haltiwanger (1992) provided some estimates to suggest that it can only account for a small part of job reallocation. Perhaps a model based on competition and innovation, such as the one developed by Ericson and Pakes (1990), would fare better. Dropping the perfect competition assumption used by all the models described in the Survey section (above) would clear the way for an analysis in which firms actively compete among themselves. There would be winners and losers; depending on the structure of the model, success would be more or less persistent. Again, it seems likely that some models of the introduction and diffusion of innovations would lead to the sort of concentration of employment gains and losses emphasized above.

At the same time, macroeconomic events do impinge on this process. There has to be a role for aggregate shocks to affect some moments of the employment growth distribution. The precise channel through which these effects are felt is clearly of interest for the modeling of aggregate labor market phenomena such as unemployment.

\section{Conclusions}

It may be helpful to collect together some of the more important conclusions from the results described above:

- Employment growth rates, job creation, job destruction, and job reallocation rates were higher at the end of the 1980s than they were at the beginning.

- Substantial diversity in those rates oc- 
curred across sectors. Even within narrow industry groups, employment growth rates ranged widely.

- Correspondingly, the job creation and job destruction rates were substantial.

- Employment growth distributions exhibit excess kurtosis: that is, there is a lot of weight both at the mean and in the tails.

- Both job creation and job destruction were extremely concentrated: about $50 \%$ of each was accounted for by just $4 \%$ of continuing establishments.

- There is evidence that employment growth was more variable in manufacturing plants than in private service sector workplaces. Considering the fact that manufacturing establishments are bigger than service sector ones, together with our finding of a negative relationship between size and variability (albeit a weak one), this is a very surprising result.

- The fortunes of a particular establishment are better characterized by persistence than by mean reversion: growing establishments tended to continue growing, and declining establishments tended to continue declining.

- Nonunion workplaces grew faster than union workplaces.

- Small workplaces grew faster than big workplaces.

- Young workplaces grew faster than older workplaces.

- Private service sector workplaces grew faster than workplaces in private manufacturing.

- Small workplaces with fewer than 100 employees accounted for a disproportionately large share of job creation and a disproportionately small share of job destruction. However, workplaces with at least 100 employees accounted for around one-half of all jobs created and three-quarters of all jobs destroyed in a one-year period.

This study confirms the main findings of the gross job flows literature for the case of manufacturing in Britain. ${ }^{15}$ In particular,

\footnotetext{
${ }^{15}$ We cannot address time series issues, because we have cross-sections at three dates only $(1980,1984$, and 1990).
}

our results confirm the existence of diverse employment growth experience and of consequent large gross flows despite modest net employment changes.

Our data, however, allow us to go much further than that. Three contributions of this study are noteworthy.

First, we have been able to examine data on establishments in both private services and the public sector. We have shown (Tables 7 and 11) that, contrary to what might have been imagined, the job reallocation rate is about the same in manufacturing as in private services (higher in the former in 1980 and 1984 , higher in the latter in 1990). The job reallocation rate in the public sector, though lower than that in the private sector, is still substantial at $7 \% .^{16}$

Second, because we also have data on unionization, we have been able to compare gross job flows between the union and nonunion sectors. We have found that job reallocation is somewhat higher in the nonunion sector, though the difference is modest in small workplaces.

Third, we present multivariate evidence on job reallocation, using all the data in our sample. We are thus able to disentangle the age and size effects, and to examine the extent of mobility between establishments within firms.

The results we have established above suggest to us that the driving forces behind the remarkable amount of job creation and destruction we have observed are likely to be found in product markets as well as labor markets. The role of product market competition in generating diverse employment outcomes seems a fruitful subject for further work; linking this mechanism with labor market features and the use of new technology, for example, may provide a model rich enough to explain the patterns we observe in the data.

\footnotetext{
${ }^{16}$ Again, recall that because we have no births or deaths, this is a lower bound.
} 


\section{REFERENCES}

Anderson, Patricia M., and Bruce D. Meyer. 1994. "The Extent and Consequences of Job Turnover." Brookings Papers on Economic Activity-Microeconomics, pp. 177-248.

Baldwin, John R., and Paul K. Gorecki. 1990. Structural Change and the Adjustment Process: Perspectives on Firm Growth and Worker Turnover. Ottawa: Canadian Government Publishing Centre.

Blanchflower, David G. 1996. "Job Creation and Job Loss: Research Questions Arising from the Use of Establishment Based Data." In Job Creation and Loss: Analysis, Policy, and Data Development. Paris: OECD.

Blanchflower, David G., and Neil Millward. 1988. "Trade Unions and Employment Change: An Analysis of British Establishment Data." European Economic Review, Vol. 32, Nos. 2-3 (March), pp. 717-26.

Blanchflower, David G., Neil Millward, and Andrew J. Oswald. 1991. "Unionization and Employment Behavior." Economic Journal, Vol. 101, No. 407, pp. 815-34.

Boeri, Tito, and Ulrich Cramer. 1992. "Employment Growth, Incumbents, and Entrants: Evidence from Germany." International Journal of Industrial Organization, Vol. 10 (December), pp. 545-65.

Bronars, Stephen G., and Donald R. Deere. 1993. "Union Organizing, Firm Growth, and the Business Cycle." American Economic Review, Vol. 83, No. 1, pp. 203-20.

Caballero, Ricardo J. 1992. "A Fallacy of Composition." American Economic Review, Vol. 82, No. 5, pp. 1279-92.

Chesher, Andrew D. 1979. "Testing the Law of Proportionate Effect." Journal of Industrial Economics, Vol. 27, No. 4 (June), pp. 403-11.

Contini, Bruno, and Riccardo Revelli. 1993. "Gross Flows vs. Net Flows: What Is There to Be Learned?" Unpublished paper, University of Turin.

Daly, Michael, Martin Campbell, Geoffrey Robson, and Colin Gallagher. 1991. "Job Creation, 1987-89: The Contributions of Small and Large Firms." Employment Gazette, Vol. 99, No. 11 (November), pp. 589-96.

Daniel, William W., and Neil Millward. 1984. Workplace Industrial Relations in Britain. London: Heinemann.

Davis, Steven J., and John Haltiwanger. 1990. "Gross Job Creation and Destruction: Microeconomic Evidence and Macroeconomic Implications." NBER Macroeconomics Annual V, pp. 123-68.

1992. "Gross Job Creation, Gross Job Destruction, and Employment Reallocation." Quarterly Journal of Economics, Vol. 107, No. 3 (August), pp. 81964

Davis, Steven J., John Haltiwanger, and Scott Schuh. 1994. "Job Creation and Destruction in U.S. Manufacturing, 1972-1988." Monograph, University of Chicago.

Dunne, Timothy, Mark J. Roberts, and Larry Samuelson. 1989a. "Plant Turnover and Gross Employment Flows in the U.S. Manufacturing Sec- tor." Journal of Labor Economics, Vol. 7, No. 1 (January), pp. 48-71.

$1989 \mathrm{~b}$. "The Growth and Failure of U.S. Manufacturing Plants." Quarterly Journal of Economics, Vol. 104, No. 4, pp. 671-98.

Freeman, Richard B., and Morris M. Kleiner, 1990. "Employer Behavior in the Face of Union Organizing Drives." Industrial and Labor Relations Review, Vol. 43, No. 4 (July), pp. 35l-63.

Gallagher, Colin C., and H. Stewart. 1986. "Jobs and the Business Life Cycle in the U.K." Applied Economics, Vol. 18, No. 8 (August), pp. 875-900.

Gallagher, Colin C., Michael J. Daly, and Jeremy Thomason. 1990. "The Growth of U.K. Companies 1985-87 and Their Contribution to Job Generation." Employment Gazette, February, pp. 9298.

Gallagher, Colin C., Michael J. Daly, and Jeremy Thomason. 1991. "The Growth of U.K. Companies and Their Contribution to Job Generation, 198587." Small Business Economics, Vol. 3, No. 4, pp. 26986.

Geroski, Paul A. 1991. Market Dynamics and Entry. Oxford: Blackwell.

Gibrat, R. 1931. Les inequalites economiques. Paris. Hamermesh, Daniel S. 1993. Labor Demand. Princeton, N.J.: Princeton University Press.

Jovanovic, Boyan. 1982. "Selection and the Evolution of Industry." Econometrica, Vol. 50, No. 3 (May), pp. 649-70.

Konings, Jozef. 1992. “Job Creation and Destruction in the U.K. Manufacturing Sector, 1972-1986: Microeconomic Evidence." Centre for Economic Performance Working Paper No. 200, London School of Economics.

Lane, Julia I., David Stevens, and Alan G. Isaac. 1992. "Workers and Jobs: Firm-Specific Contributions to Worker Turnover." Unpublished paper, American University, Washington.

Leonard, Jonathan S. 1992. "Unions and Employment Growth." Industrial Relations, Vol. 31, No. 1 (January), pp. 80-94.

Leonard, Jonathan S., and Marc A. van Audenrode. 1993. "Corporatism Run Amok: Job Stability and Industrial Policy in Belgium and the United States." Economic Policy, Vol. 17, pp. 355-400.

Lilien, David M. 1982. "Sectoral Shifts and Cyclical Unemployment." Journal of Political Economy, Vol. 90, pp. 777-93.

Long, Richard J. 1993. "The Impact of Unionization on Employment Growth of Canadian Companies." Industrial and Labor Relations Review, Vol. 48, No. 4 (July), pp. 691-93.

Millward, Neil, and Mark Stevens. 1986. British Workplace Industrial Relations, 1980-1984. Aldershot: Gower Press.

Millward, Neil, Mark Stevens, David Smart, and William R. Hawes. 1992. Workplace Industrial Relations in Transition. Aldershot: Dartmouth.

Nickell, Stephen J., and Sushil Wadhwani. 1991. "Employment Determination in British Industry: 
Investigations Using Micro Data." Review of Economic Studies, Vol. 55, No. 5 (October), pp. 955-70.

Organization of Economic Cooperation and Development. 1994. "Job Gains and Job Losses in Firms." In Employment Outlook 1994. Paris: OECD, pp. 10335.

Pakes, Ariel, and Richard Ericson. 1990 "Empirical Implications of Alternative Models of Firm Dynamics." Working paper, Yale University.

Storey, David, J. 1985. "Manufacturing Employment
Change in Northern England, 1965-78: The Role of Small Businesses." In David J. Storey, ed., Small Firms in Regional Economic Development: Britain, Ireland, and the United States. Cambridge: Cambridge University Press.

Wagner, Joachim. 1992. "Firm Size, Firm Growth, and Persistence of Change: Testing Gibrat's Law with Establishment Data from Lower Saxony." Small Business Economics, Vol. 4, No. 2, pp. 12532. 
Copyright of Industrial \& Labor Relations Review is the property of Cornell University. The copyright in an individual article may be maintained by the author in certain cases. Content may not be copied or emailed to multiple sites or posted to a listserv without the copyright holder's express written permission. However, users may print, download, or email articles for individual use. 